\title{
Muscles of mastication and the temporo-mandibular joint of the Saimaa (Pusa hispida saimensis) and Baltic (Pusa hispida botnica) ringed seals
}

\author{
Juha Laakkonen ${ }^{1, *} \&$ Jukka Jernvall ${ }^{2}$
}

1) Division of Veterinary Anatomy and Developmental Biology, Department of Veterinary Biosciences, Faculty of Veterinary Medicine, P.O. Box 66, Fl-00014 University of Helsinki, Finland ("corresponding author's e-mail: juha.laakkonen@helsinki.fi)

2) Institute of Biotechnology, P.O. Box 56, Fl-00014 University of Helsinki, Finland

Received 1 July 2019, final version received 20 Nov. 2019, accepted 18 Nov. 2019

Laakkonen, J. \& Jernvall, J. 2020: Muscles of mastication and the temporo-mandibular joint of the Saimaa (Pusa hispida saimensis) and Baltic (Pusa hispida botnica) ringed seals. - Ann. Zool. Fennici 57: 21-29.

\begin{abstract}
As part of our research aiming to understand the morphological variation in ringed seals, we dissected mastication muscles of nine Saimaa ringed seals and two Baltic ringed seals. We found no significant differences in the muscles of mastication between these subspecies but the location of the tympanic bulla in relation to the articular surface of the temporomandibular joint was more medial in the Saimaa ringed seal. As compared with the previously studied Baikal and Caspian seals, the origin of the jaw-opening digastricus muscle covered less of the tympanic bulla in the Saimaa and Baltic ringed seals. Our data on masticatory-muscle masses indicated that similarly to terrestrial mammal species, the growth patterns of mastication muscles of the Saimaa ringed seal differed from each other according to the body size.
\end{abstract}

\section{Introduction}

Comparison of morphological and functional traits among closely related species can reveal behavioral traits and adaptations to various habitats. While teeth are arguably the most important morphological indicators of the feeding strategies and diet of a mammal, the muscles of mastication can provide additional information about the ways that food is acquired and processed at the rostral end of an animal's digestive tract. Dentition is brought into use by the jaw-closing musculature, which in mammals is comprised of four distinct muscles: temporalis (musculus temporalis), masseter (musculus masseter), and the two pterygoids (musculus pterygoideus lateralis and medialis) (Dyce et al. 2010). The digastricus (musculus digastricus) is the sole jaw-opening muscle (but see Druzinsky 2010).

As part of our research aiming to understand the morphological variation in ringed seals, we studied the muscles of mastication of the Saimaa ringed seal (Pusa hispida saimensis) and the Baltic ringed seal (Pusa hispida botnica) as well as the skull morphology associated with these muscles. The Saimaa ringed seal is one of the most endangered seals, with roughly 400 individuals left, thus offering an excellent opportunity to study the phenotypic consequences of an extreme genetic bottleneck in great detail. While 
genetic differentiation between ringed seals from the Baltic and Arctic Seas is low-to-moderate, it is high between these populations and the Saimaa ringed seal population (Valtonen et al. 2012, Martinez-Bakker et al. 2013, Savriama et al. 2018), which is thought to have originated from the Baltic population and became landlocked about 9500 years ago (Valtonen et al. 2012, Ukkonen et al. 2014). Whether this genetic differentiation is reflected in significant morphological differences between the Saimaa and Baltic ringed seals, however, has not been determined. One minor difference between the Saimaa and marine ringed seals has been noted, which is the origination point of the first segmental bronchus from the right caudal lobar bronchus (Laakkonen \& Jernvall 2016). Although the marine ringed seals used for comparison in that study originated from Alaska (Smodlaka et al. 2009), the same difference has since been observed between the Saimaa and Baltic ringed seals (first author's unpubl. data). The Saimaa ringed seal's asymptomatic body mass is reported to be $59 \mathrm{~kg}(55.8-62.4, n=113)$, which is similar to that of medium sized marine ringed seals (Auttila et al. 2016).

Magnetic resonance imaging has indicated that the masseter and temporalis are the most prominent jaw muscles in the Saimaa ringed seal (Usenius et al. 2007), however further information about the muscles of mastication in this species is scarce. While thoroughly examined in the Baikal seal (Phoca sibirica) and the Caspian seal (Phoca caspica) (Endo et al. 1998, 1999, 2002), similar studies of marine ringed seals have not been conducted. Endo et al. (1998, 1999, 2002) argue that the enlarged orbit of the Baikal and Caspian seals has affected the form and function of their muscles of mastication. The Saimaa ringed seal possesses the same thin frontal bone and dorso-ventrally developed zygomatic arch found in the Baikal and Caspian seals, required to provide space for the enlarged eyeball in the orbit (Hyvärinen \& Nieminen 1990, Endo et al. 1998, 2002). The Saimaa ringed seal, however, has relatively large mandibles and wide zygomatics, yet short tooth rows (Hyvärinen \& Nieminen 1990, Amano et al. 2002). Similar to the marine ringed seal (Chapskii's 1955 as cited in Endo et al. 2002), the Saimaa ringed seal has also been reported to possess a more robust and more laterally located tympanic bulla than that of the Baikal and Caspian seals (Hyvärinen \& Nieminen 1990, Endo et al. 1998, 2002, Amano et al. 2002). Hyvärinen and Nieminen (1990) reported that the tympanic bulla of the Saimaa ringed seal has a higher dorso-ventral diameter than that of the Baltic ringed seal. It has been assumed that the large bulla is associated with a good sense of hearing, and reflects an adaptation to low visibility in the dark waters of Lake Saimaa (Hyvärinen \& Nieminen 1990). On the other hand, Amano et al. (2002) suggested that the distinct skull proportions are a result of the diet of the Saimaa ringed seal.

The Saimaa ringed seal is a generalist carnivore that feeds on a minimum of 15 species of fish, but mainly relies on the most abundant small schooling fish (Kunnasranta et al. 1999, Auttila et al. 2015), which are caught by rapid forward movements of the head and neck (M. Kunnasranta pers. comm.). Crustaceans are almost absent from the diet of the Saimaa ringed seal (Kunnasranta et al. 1999, Auttila et al. 2015). Similar to other pinnipeds (Berta et al. 2006, Jones et al. 2013), the role of oral food processing appears to be limited in the Saimaa ringed seal, since most fishes found in their stomachs do not have clear bite marks (first author's pers. obs.). Limited oral processing of prey is also evident in the ringed seal's postcanine dentition, which lack exact occlusion and is highly variable (Jernvall 2000). The Baltic ringed seals are also generalist fish feeders but their diet includes also large benthic invertebrates like isopods (Sinisalo et al. 2008). Thus, there may be some minor differences in the position and attachments of muscles of mastication between the Saimaa and the Baltic ringed seals. It should be noted, however, that both/ either the long isolation period of the Saimaa ringed seal and/or bottleneck effects might have caused rapid fixation of morphological traits that are not related to the functional anatomy of the muscles of mastication. Also, the need to store the specimens in freezers prior to the dissection, may result in desiccation of the muscles. This in turn may result in decreased muscle weights which has to be considered when comparing the absolute weights among studies. 


\section{Material and methods}

All Saimaa ringed seals that are found dead are collected by the staff of the Parks and Wildlife of Metsähallitus (a state institution that administers state-owned land and water areas), stored at $-20{ }^{\circ} \mathrm{C}$, and examined at the Oulu unit of the Finnish Food Authority where various tissue samples are collected for the long-term monitoring of the health of the seals. Specimens are usually in various stages of decomposition, preventing any detailed morphological studies. In 2013-2018, a total of seven Saimaa ringed seals were examined as part of the routine necropsies (Table 1). The seals examined were either by-catch found in gill nets, or found dead (with various causes of death). Most of the by-catch individuals were pups ( $\leq 12$ months) or young (under three years old), however one individual examined was clearly an adult $(>50 \mathrm{~kg})$. The ages of the seals were determined by counting the cementum layers in the lower canine teeth (Stewart et al. 1996), or estimated in individuals without a good quality tooth sample. In addition to the seven specimens examined during the routine necropsies, two Saimaa ringed seals that were found dead, as well as two Baltic ringed seals that were legally shot by a hunter in the northern Baltic Sea (Kalajoki; Table 1) were shipped frozen to the Veterinary Faculty of the University of for anatomical dissections. All seals were weighted prior the dissection. After the masticatory muscles were identified, they were separated and detached from their bone attachments. Muscle weights were recorded immediately upon removal with a digital platform scale (Pesola ${ }^{\circledR}$ PTS3000) to the nearest $0.1 \mathrm{~g}$. The proportional mass of each muscle was examined against the total body weight and the significance of patterns was tested with non-parametric tests (Kruskal-Wallis and Jonckheere-Terpstra test for ordered alternatives, IBM SPSS Statistics 25). The data for the Baltic ringed seal were excluded from the statistical analyses due to the small sample size. The anatomical terminology is in accordance with the International Committee on Veterinary Gross Anatomical Nomenclature (2017). One of the authors (JL) examined additional skull specimens for comparative purposes. Skull specimens are listed here by the museum catalog numbers: University of Eastern Finland, Joensuu, Finland: Pusa hispida saimensis: 2483, 2497, 2504, 2507, 2510; Natural History Museum in Helsinki, Finland: Pusa hispida saimensis: 112, 6462, 5689, 5703, 5704, 6462, 6728; Pusa hispida botnica 2279, 2113; Pusa hispida ladogensis: 1275, 1276, 2148, 2149; Pusa sibirica 2927; Pusa

Table 1. Weight of the muscles of mastication (right and left side) of nine Saimaa ringed seal specimens and two Baltic ringed seal specimens, identified with their sampling codes. In some cases, the muscle weight (in grams) is missing due to tissue damage or deteriorated condition of the muscle, or because the blood vessels of the muscle area were injected with silicone for a separate study. The masseter of each side was weighed as one entity because the two parts of the muscle could not be separated cleanly.

\begin{tabular}{|c|c|c|c|c|}
\hline Specimen & Temporalis & Masseter & Pterygoids & Digastricus \\
\hline \multicolumn{5}{|l|}{ Saimaa ringed seals } \\
\hline 2623, male, 70 kg, 11 years & $32.4 / 32.2$ & $24 / 24.6$ & - & $18.7 / 18.6$ \\
\hline 2670 , female, $42 \mathrm{~kg}, 2$ years $^{\#}$ & $14.0 / 14.8$ & $8.4 / 9.0$ & $3.9 / 3.2$ & $8.2 / 8.5$ \\
\hline $2698^{*}$, male, 38 kg, 2 years ${ }^{\#}$ & $13.6 /-$ & $10.4 /-$ & - & $9.5 /-$ \\
\hline 2563, male, 36 kg, 10 months & $15.8 / 15.7$ & $8.4 / 8.5$ & $3.9 / 4.1$ & $9.0 / 9.2$ \\
\hline 2593, male, $35 \mathrm{~kg},>12$ months $^{\#}$ & $14.4 / 15.2$ & $8.3 / 8.5$ & $3.8 / 4.3$ & 9.5/9.6 \\
\hline 2621 , male, $33 \mathrm{~kg},>12$ months ${ }^{\#}$ & $15.7 / 16.2$ & $10.7 / 10.4$ & - & $12.4 / 12.6$ \\
\hline 2585 , female, $21 \mathrm{~kg}, 4$ months & $6.8 / 6.5$ & $5.5 / 5.8$ & $4.2 / 3.9$ & 6.9/6.8 \\
\hline 2616 , male, $18 \mathrm{~kg}, 4.5$ months & $6.6 / 6.5$ & $5.2 / 5.0$ & $4.2 / 3.9$ & $6.8 / 7.0$ \\
\hline 2615 , female, $14 \mathrm{~kg}, 4.5$ months & $3.9 / 4.2$ & 3.9/3.3 & $1.2 / 1.2$ & $5.1 / 4.9$ \\
\hline \multicolumn{5}{|l|}{ Baltic ringed seals } \\
\hline 459, female, 46 kg, > 12 months ${ }^{\#}$ & $15.6 / 14.9$ & $9.7 / 9.4$ & 3.6/3.3 & $10.5 / 9.6$ \\
\hline $458^{*}$, female, $23 \mathrm{~kg},<12$ months ${ }^{\#}$ & $5.7 /-$ & $4.3 /-$ & $2.3 /-$ & $4.2 /-$ \\
\hline
\end{tabular}

\footnotetext{
" age was estimated, * only right side.
} 


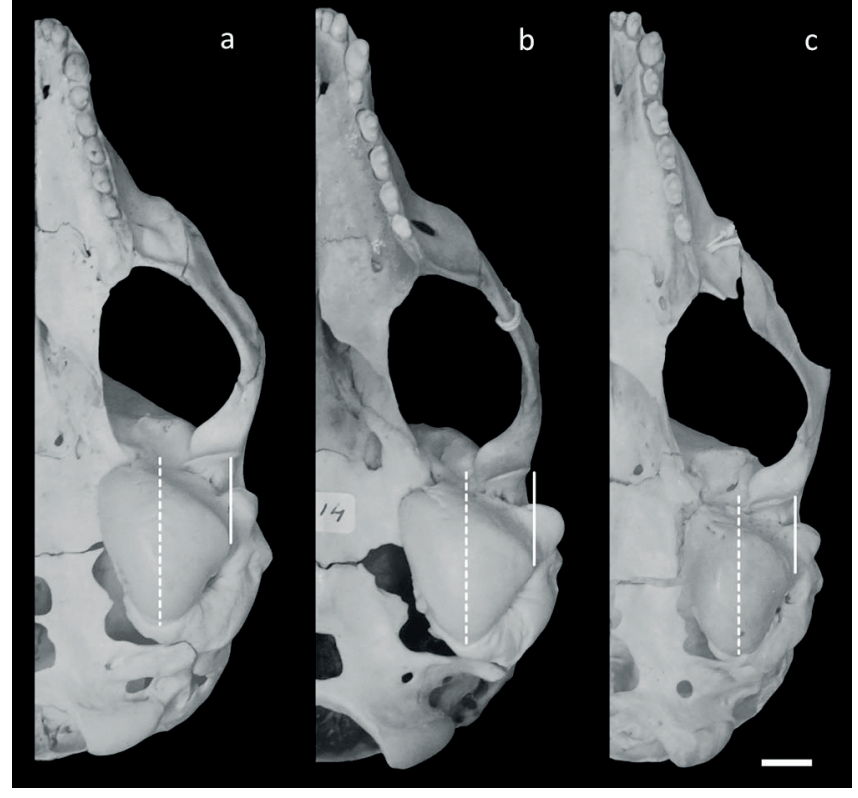

Fig. 1. Ventral aspect of the skull of adult (a) Saimaa, (b) Baltic, and (c) Baikal ringed seals showing the location of the lateral edge of the tympanic bulla in relation to the articular surface of the temporomandibular joint (the vertical lines). The dashed line indicates the medial edge of attachment of the digastricus muscle. All animals were one-year-old. Scale bar $=1 \mathrm{~cm}$. caspica 7/1968, 8/1968; The California Academy of Sciences in San Francisco, USA: marine (from Alaska) Phoca hispida 21103, 10166 and Phoca vitulina: 23257, 23752, 23796, 28482, 28483, 28545, 28751,28674, 28751, 29232, 29233, 29234, 29284, 29431, 29442, 29865, 29871, 29885, 30022 30089, 30091, 30094, 30096, 30100 .

\section{Results}

The temporomandibular joint of the Saimaa and the Baltic ringed seals was situated approximately at the level of the occlusal plane, with the canine and incisive teeth slightly dorsal in relation to the joint. The location of the tympanic bulla in relation to the articular surface (facies articularis) of the temporomandibular joint was more medial in the Saimaa ringed seal than in the Baltic ringed seal (Fig. 1) as well as in Pusa sibirica (Fig. 1), Pusa hispida ladogensis, Pusa caspica, and Phoca vitulina (not shown).

The mass ( $\mathrm{g}$ ) of the individual jaw muscles is presented in Table 1. The contributions of individual jaw-closing muscles to the combined muscle mass in Saimaa ringed seals was calculated using the data from the three young individuals $(2563,2593,2670)$ for which the complete weight data were available. The temporalis muscle, the masseter and the pterygoids contributed $54.0 \%-55.9 \% \quad($ mean $=54.2 \%)$, $29.6 \%-32.6 \% \quad($ mean $=31.1 \%)$ and $13.3 \%-$ $14.9 \%($ mean $=14.1 \%)$ to the total jaw-closing muscle mass, respectively. The contribution of the sole jaw-opening muscle, digastricus, to the total mass of the muscles of mastication varied between $23.9 \%$ and $27.3 \%$ (mean $=24.7 \%$ ). For the Baltic ringed seals, the contribution of individual jaw-closing muscles to the total jaw-closing muscle mass was calculated using the data from just one, adult individual (459) for which the complete muscle weight data were available. The temporalis muscle, the masseter and the pterygoids contributed $54.0 \%, 33.8 \%$ and $12.2 \%$ to the total jaw-closing muscle mass, respectively. The contribution of the digastricus to the total mastication muscle mass was $26.2 \%$.

The masticatory muscles showed a change in weight proportions depending on the body size of the seals (Fig. 2). Compared with the other jaw muscles, the digastricus was relatively heavier in small (young) individuals after which its' growth slowed down, while the temporalis became proportionally larger (Fig. 2). The trends in the proportional mass of each muscle related the total body weight were not statistically significant when tested with a standard non-para- 

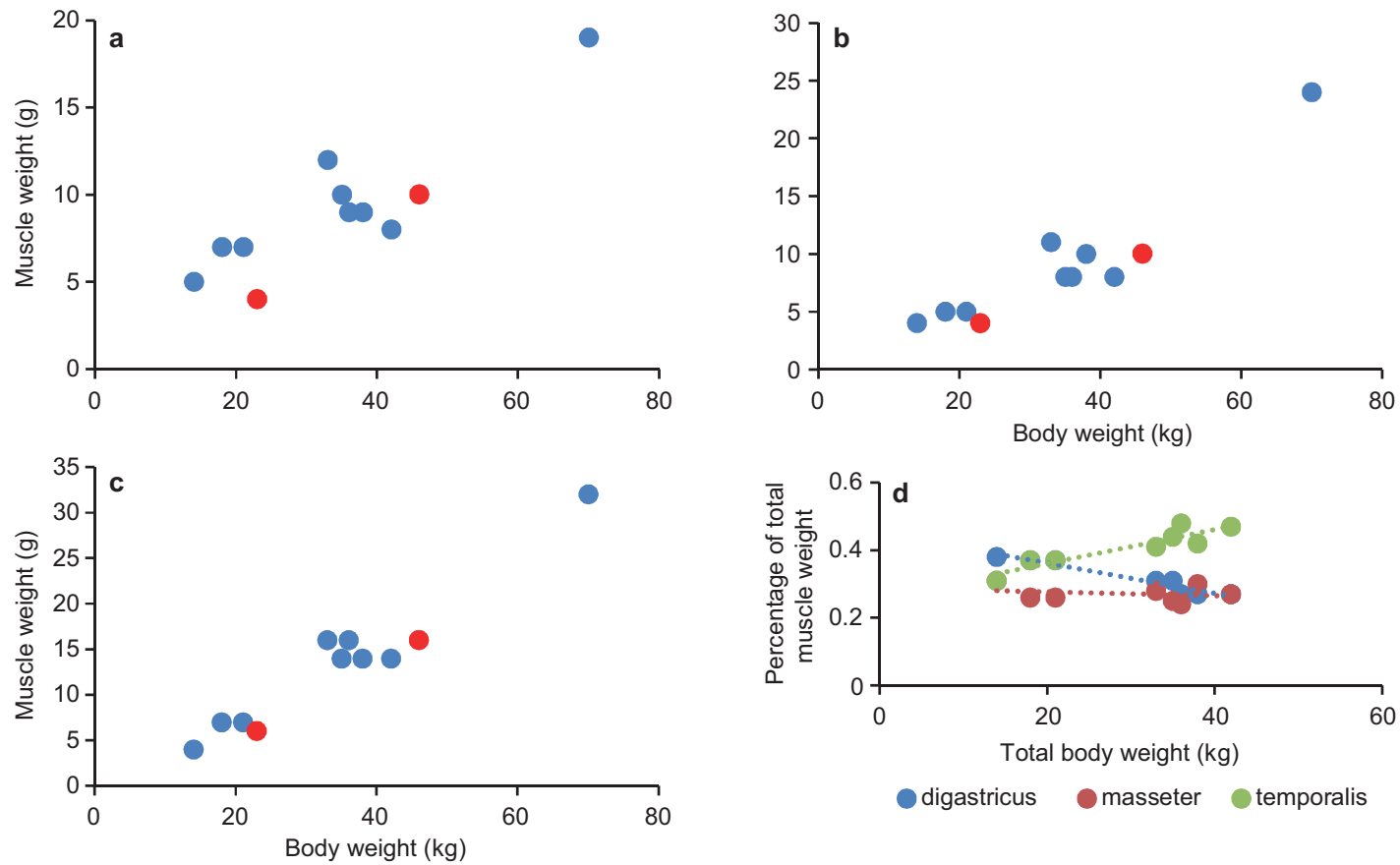

Fig. 2. The muscle weight proportions (a: digastricus, b: masseter, c: temporalis) in different Saimaa (blue dots) and Baltic ringed seal (red dots) body-size groups. Only muscles from the right side were included to allow as large a sample size as possible. The pterygoids were excluded from this comparison as their weight changes very little (Table 1). (d) The proportional mass of each muscle against the total body weight (the Baltic ringed seal data were excluded due to the small sample size, as well as one large Saimaa ringed seal individual as an outlier).

metric test, but when a priori ordering of samples according to the body weight was used (Jonckheere-Terpstra test), the trends became significant for temporalis $(p=0.016)$ and digastricus $(p=0.001)$ but not for masseter $(p=0.753$; Fig. 2d). The removal of the one large individual (as an outlier) slightly altered the $p$ values (not shown) but it did not change the overall result.

Individual muscles were considered as follows:

Digastricus: This muscle pulls the jaw ventrally and to a lesser degree, caudally. The larger of the two digastricus bellies (venter caudalis) originated from the jugular process. In both the Saimaa and the Baltic ringed seals, this caudal part of the digastricus also attached laterally and caudally around the tympanic bulla before inserting to the tendinous intersection of the rostral part of this muscle (Fig. 3). The rostral part of the digastricus (venter rostralis) originated from the tendinous intersection between the two parts of this muscle before inserting mainly to the ventro-lateral side of the mandibular body (Fig. 3). In one Saimaa ringed seal individual, the rostral part of this muscle inserted partly also to the medial side of the mandible. The muscle fibers ran caudo-rostrally parallel to the mandible.

Masseter: This muscle, which pulls the mandible dorsally, lay on the lateral surface of the ramus mandible. It originated from the zygomatic arch, and inserted into the ventral and caudal borders of the mandible. It was partly covered by a strong aponeurosis, and tendinous muscle fibers were intermingled throughout the muscle, although only a superficial and a deep part could be easily distinguished. The muscle fibers of the superficial part ran caudo-ventrally, and those of the deep part ran dorso-ventrally. The deep part originated from the zygomatic arch with a strong tendon, intermingled with the tendons of the temporalis muscle, and inserted into the masseteric fossa. The deep part of the 

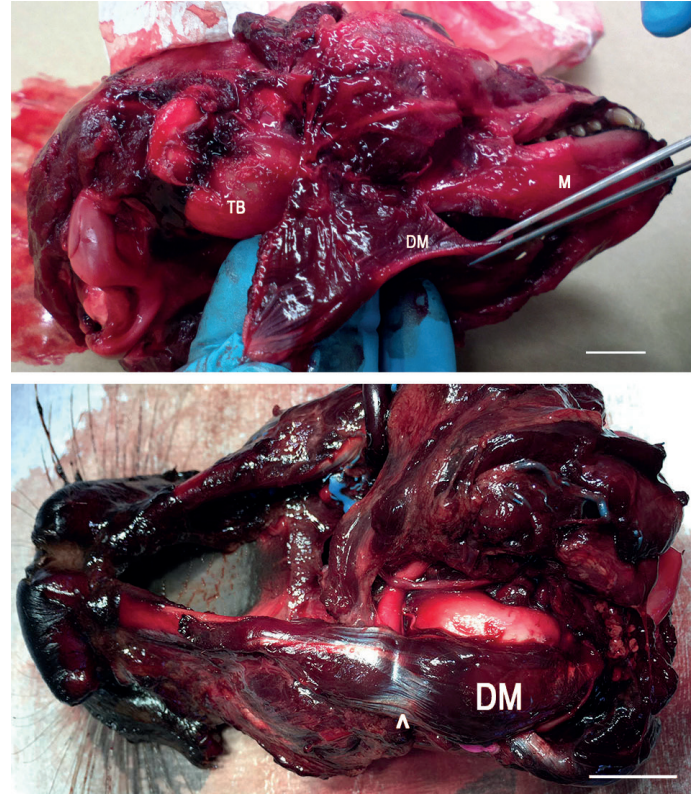

Fig. 3. - a: Latero-ventral aspect of the Saimaa ringed seal skull showing the digastricus muscle (DM) removed from the lateral and ventral side of the tympanic bulla (TB) and mandible $(\mathrm{M})$; scale bar $=1 \mathrm{~cm}$. - b: Ventral aspect of the skull of a Baltic ringed seal specimen showing the intact digastricus muscle (DM) partly covering the tympanic bulla. The tendinous intersection between the two parts of this muscle is indicated by the arrowhead; scale bar $=2 \mathrm{~cm}$.

muscle was smaller than the superficial part, and the muscle fibers run more vertically from the zygomatic arch to the masseteric fossa than those of the superficial part.

Temporalis: This muscle pulls the jaw directly upwards and to a lesser degree, backwards. The temporalis muscle originated from the large temporal fossa, extending over most of the latero-dorsal surface of the skull behind the orbit, as well as on the shelf-like caudal part of the arcus zygomaticus. The muscle inserted into both sides of the coronoid process of the mandible, although the attachment on the medial side was larger. The fibers of the temporalis, which ran ventro-rostrally, converged on a tendon that ran through the middle of the muscle. The temporalis muscle was separated from the orbit by the orbital ligament and a fascia that protected the eye, from the caudal side. There was also a considerable amount of orbital fat in this area in both ringed seal species. The superficial part of the temporalis muscle accounted for approximately two thirds of the thickness of this muscle. A thin white tendon separated the superficial part from the thinner deep part. The muscle was weighed as one entity because the two parts could not be separated cleanly (Table 1).

Pterygoids: The medial muscle originated from the lateral area of the pterygoid and sphenoid bones, and inserted into the medio-caudal surface of the mandible caudal to the masseter, extending rostrally just over the angular process. The lateral muscle, which was difficult to distinguish from the medial muscle, arose from the sphenoid bone, and appeared to be medially attached to the capsula articularis of the jaw joint just ventral to the articular surface. The fibers of both muscles ran ventro-laterally.

\section{Discussion}

Our data show that the masticatory muscle anatomy of the Saimaa and Baltic ringed seals is largely similar to that reported in the Baikal and Caspian seals (Endo et al. 1998, 2002). Nevertheless, the origin of the jaw-opening digastricus muscle did not cover the entire medial side of the tympanic bulla in the Saimaa and Baltic ringed seals as it appears to do in the Baikal and Caspian seals (Endo et al. 1998, 2002). In addition, the digastricus of the ringed seals examined in this study had a partly lateral insertion on the mandible while Endo et al. (2002) reported that the rostral belly of digastricus inserted partly to the ventro-medial surface of the mandibular body. We found a similar ventro-medial insertion only in one Saimaa ringed seal individual. Whether these differences are partly age-depended is not known because the age of the Baikal and Caspian seals was not reported (Endo et al. 1998, 2002). Also, it remains to be studied whether these differences significantly affect the function of the temporomandibular joint.

The mammalian postnatal development of the jaw is characterized by a transformation of the orofacial system from a suckling into a masticatory apparatus. The growth rate of the 
individual muscles of mastication may be part of this transition as differences in growth rates have been reported from several species (Müller 1933, Cachel 1984, Herring \& Wineski 1986, Hurov et al. 1988, Langenbach \& Weijs 1990). A general trend in mammals seems to be the early growth of jaw openers and the ventral muscles of the mouth as these muscles are involved in suckling (Herring 1985). Similarly to other mammalians (Müller 1933, Cachel 1984, Hurov et al. 1988, Langenbach \& Weijs 1990), the contribution of the digastricus of the Saimaa and Baltic ringed seals to the total jaw muscle weight decreased with increased body size (age) (Fig. 2). This is intriguing as these muscles are also involved in suction feeding utilized by many pinnipeds. Also in the Saimaa ringed seal, the temporalis had a strong positive allometric growth (Fig. 2). In terrestrial carnivores, this muscle is important in producing the killing bite force. Of the other masticatory muscles, the contribution of the masseter to the total muscle weight increases with age in many herbivores and omnivores (Müller 1933, Herring \& Wineski 1986, Hurov et al. 1988, Langenbach \& Weijs 1990), possibly because of the importance of this muscle (together with the pterygoids) in lateral movements of the jaw (Herring \& Wineski 1986). In the Saimaa ringed seal, no significant trend was evident in the proportional mass of this muscle with increasing body weight (Fig. 2). However, more data on mastication muscles of adult individuals are needed to confirm the growth patterns documented in this study.

In interpreting the variable growth patterns of masticatory muscles, it should be noted that the cranial growth itself, as well as the space needed by the brain and eyes may limit the available space and attachment of areas for masticatory muscles and thereby determine differential growth. It should be also noted, that adipose tissue can form a significant proportion of the body mass in seals. Although the muscles of the individuals examined in this study may have lost some of their mass due to storage in the freezer after death, the mass of the muscles of mastication in ringed seals appears to be remarkably low compared to that of similar-sized terrestrial mammals (Hartstone-Rose et al. 2012). This indicates that the bite force of ringed seals is relatively low but information on fiber length and physiological cross-sectional areas of the muscles is needed to confirm this.

The feeding kinematics of the Saimaa and Baltic ringed seals has not been studied in detail. The temporomandibular joint of the Saimaa and Baltic ringed seals was situated approximately at the level of the occlusal plane with the canine and incisor teeth slightly dorsal of the joint, indicating that there is little need for lateral movement of the jaw (Dyce et al. 2010). This is supported by the lack of any trend in the proportional mass of the masseter muscle with increasing body weight in the Saimaa ringed seal. The skull of these subspecies is apparently not under significant cranial strain from any muscles of mastication, because they prey on small-sized fish (Sinisalo et al. 2008, Kunnasranta et al. 1999, Auttila et al. 2015). Moreover, similar to other ringed seals (Stirling 1977), they do not use their teeth for scraping ice to form breathing holes; rather, they mainly rely on their claws for this. Finally, they do not demonstrate extreme combative behaviors typical of some other pinnipeds (Jones et al. 2013). Nevertheless, the difference in the location of the tympanic bulla in relation to the temporo-mandibular joint between the Saimaa and Baltic ringed seals (Fig. 1) reported here is interesting because it may affect the range of motion of the digastricus muscle. Previous studies (Hyvärinen \& Nieminen 1990, Endo et al. 1998, 2002) suggest that the zygomatic arch provides space for the enlarged eyeball in the orbit of ringed seals, but the shape of the zygomatic arch also affects the location and shape of the articular surface of the temporo-mandibular joint. Detailed comparative studies with data sets of computer scanned skulls covering all ages are warranted to investigate how exactly the dorso-ventral diameter of the tympanic bulla varies according to the age of the seal, and whether there are any differences between subspecies in this respect.

Research on the feeding kinematics of a closely related species, the harbor seal (Phoca vitulina, Marshall et al. 2014), showed that their diet includes larger sized prey than those consumed by the Saimaa and Baltic ringed seals (Härkönen 1987, Olsen \& Bjørge 1995). Additionally, they have a wide repertoire of opportu- 
nistic feeding strategies (see also Kienle \& Berta 2016) such as suction and hydraulic jetting, which in addition to action of the mastication muscles, involve movements of the tongue of these secondarily aquatic carnivores (see also Churchill \& Clementz 2015).

\section{Acknowledgements}

We received funding for our seal research from the University of Helsinki (JL), the Academy of Finland, and the Jane and Aatos Erkko Foundation (JJ). We thank members of the Metsähallitus seal group, especially Jouni Koskela for the collection and background information of the specimens, Marja Isomursu DVM for the necropsies of the specimens in Oulu, and Heini Nihtilä for help with dissections. Maureen Flannery provided us access to the collections of the California Academy of Sciences in San Francisco, Voitto Haukisalmi and Martti Hildén to the collections of the Natural History Museum in Helsinki. Mervi Kunnasranta and Mia Valtonen are thanked for their help with the museum specimens in the University of Eastern Finland collections, as well as with background information on phocid biology.

\section{References}

Amano, M., Hayano, A. \& Miyazaki, N. 2002: Geographic variation in the skull of the ringed seal, Pusa hispida. Journal of Mammalogy 83: 370-380.

Auttila, M., Sinisalo, T., Valtonen, M., Niemi, M., Viljanen, M., Kurkilahti, M. \& Kunnasranta, M. 2015: Diet composition and seasonal feeding patterns of a freshwater ringed seal (Pusa hispida saimensis). - Marine Mammal Science 31: 45-65.

Auttila, M., Kurkilahti, M., Niemi, M., Levänen, R., Sipilä, T., Isomursu, M., Koskela, J. \& Kunnasranta, M. 2016: Morphometrics, body condition, and growth of the ringed seal (Pusa hispida saimensis) in Lake Saimaa: implications for concervation. - Marine Mammal Science 32: 252-267.

Berta, A., Sumich, J. \& Kovaks, K. 2006: Marine mammals: evolutionary biology. - Academic Press, San Diego, USA.

Cachel, S. 1984: Growth and allometry in primate masticatory muscles. - Archives of Oral Biology 29: 287-293.

Churchill, M. \& Clementz, M. T. 2015: Functional implications of variation in tooth spacing and crown size in Pinnipedimorpha (Mammalia: Carnivora). - Anatomical Record 298: 878-902.

Cox, P. G. 2008: A quantitative analysis of the Eutherian orbit: correlations with masticatory apparatus. - Biological Reviews 83: 35-69.

Druzinsky, R. E. 2010: Functional anatomy of incisal biting in Aplodontia rufa and sciuromorph rodents - Part 2. Sciuromorphy in efficacious for production of force at the incisors. - Cells Tissues Organs 192: 50-63.

Dyce, K. M., Sack, W. O. \& Wensing, C. J. G. 2010: Textbook of veterinary anatomy, 4 th ed. - W.B. Saunders Co., Philadelphia, PA.

Endo, H., Sasaki, H, Hayashi, Y., Petrov, E. A., Amano, M. \& Miyazaki, N. 1998: Functional relationships between muscles of mastication and the skull with enlarged orbit in the Baikal Seal (Phoca sibirica). - Journal of Veterinary Medical Science 60: 699-704.

Endo, H., Sasaki, H., Hayashi, Y., Petrov, E. A., Amano, M., Suzuki, N. \& Miyazaki, N. 1999: CT examination of the head of the Baikal seal (Phoca sibirica). - Journal of Anatomy 194: 119-126.

Endo, H., Sakata, S., Arai, T. \& Miyazaki, N. 2002: The muscles of mastication in the Caspian seal (Phoca hispida). - Anatomia Histologia Embryologia 31: 262-265.

Hartstone-Rose, A., Perry, J. M. G. \& Morrow, C. J. 2012: Bite force estimation and the fiber architecture of felid masticatory muscles. - Anatomical Record 295: 13361351.

Herring, S. W. 1985: The ontogeny of mammalian mastication. - American Zoology 25: 339-349.

Herring, S. W. \& Wineski, L. E. 1986: Development of the masseter muscle and oral behavior in the pig. - Journal of Experimental Zoology 237: 191-207.

Hurov, J., Henry-Ward W., Philips, L. \& German, R. 1988: Growth allometry of craniomandibular muscles, tendons, and bones in the laboratory rat (Rattus norvegicus): relationships to oromotor maturation and biomechanics of feeding. - American Journal of Anatomy 182: 381-394.

Hyvärinen, H. \& Nieminen, M. 1990: Differentation of the ringed seal in the Baltic Sea, Lake Ladoga and Lake Saimaa. - Finnish Game Research 47: 21-27.

Härkönen, T. 1987: Seasonal and regional variations in the feeding habits of the harbour seal, Phoca vitulina, in the Skagerrak and the Kattegat. - Journal of Zoology 213: 535-543.

International Committee on Veterinary Gross Anatomical Nomenclature 2017: Nomina anatomica veterinaria, 6th ed. - International Committee on Veterinary Gross Anatomical Nomenclature, World Association of Veterinary Anatomists.

Jernvall, J. 2000: Linking development with generation of novelty in mammalian teeth. - Proceedings of the National Academy of Sciences of the USA 97: 26412645.

Jones, K. E., Ruff, C. B. \& Goswami, A. 2013: Morphology and biomechanics of the pinniped jaw: mandibular evolution without mastication. - Anatomical Record 296: 1049-1063.

Kienle, S. S. \& Berta, A. 2016: The better to eat you with: the comparative feeding morphology of phocid seals (Pinnipedia, Phocidae). - Journal of Anatomy 228: 396-413.

Kunnasranta, M., Hyvärinen, H., Sipilä, T. \& Koskela, J. T. 1999: The diet of the Saimaa ringed seal Phoca hispida saimensis. - Acta Theriologica 44: 443-450.

Laakkonen, J. \& Jernvall, J. 2016: Macroscopic anatomy of the Saimaa ringed seal (Phoca hispida saimensis) lower respiratory tract. - Anatomical Record 299: 538-543. 
Langenbach, G. E. \& Weijs, W. A. 1990: Growth patterns of the rabbit masticatory muscles. - Journal of Dental Research 69: 20-25.

Martinez-Bakker, M. E., Sell, S. K. \& Swanson, B. J. 2013: Combined genetic and telemetry data reveal high rates of gene flow, migration, and long-distance dispersal potential in Arctic ringed seals (Pusa hispida). PLOS ONE 8: e77125, https://doi.org/10.1371/journal. pone.0077125.

Marshall, C. D., Wieskotten, S., Hanke, W., Hanke, F. D., Marsh, A., Kot, B. \& Dehnhardt, G. 2014: Feeding kinematics, suction, and hydraulic jetting performance of harbor seals (Phoca vitulina). — PLoS ONE 9: e86710, https://doi.org/10.1371/journal.pone.0086710.

Müller, A 1933: Die Kaumuskulatur des Hydrochoerus cabyvara und ihre Bedeutung für die Formgestaltung des Schädels. - Gegenbaurs Morphologishe Jahrbuch 72: 1-59.

Olsen, M. \& Bjørge, A. 1995: Seasonal and regional variations in the diet of harbour seal in Norwegians waters. - Developments in Marine Biology 4: 271-285.

Savriama, Y., Valtonen, M., Kammonen, J. I., Rastas, P., Smolander, O.-P., Lyyski, A., Häkkinen, T. J., Corfe, I. J., Gerber, S., Salazar-Ciudad, I., Paulin, L., Holm, L., Löytynoja, A., Auvinen, P. \& Jernvall, J. 2018: Bracketing phenotypic limits of mammalian hybridization. — Royal Society Open Science 5: 180903, http://dx.doi. org./10.1098/rs.180903.

Sinisalo, T., Jones, R. I., Helle, E. \& Valtonen, E. T. 2008: Changes in the diet of individual Baltic ringed seals (Phoca hispida botnica) during their breeding season inferred from stable isotope analysis of multiple tissues. - Marine Mammal Science 24: 159-170.

Stewart, R. E. A, Stewart, B. E., Stirling, I. \& Street, E. 1996:
Counts of growth layer groups in cementum and dentine in ringed seals (Phoca hispida). — Marine Mammal Science 12: 383-401.

Stirling, I. 1977: Adaptations of Weddell and ringed seals to exploit the polar fast ice habitat in the absence or presence of surface predators. - In: Llano, G. A. (ed.), Adaptations within Antarctic ecosystems. Proceedings of the 3rd Scientific Committee on Antarctic Research Symposium on Antarctic Biology, Washington, DC, USA: 741-748. Smithsonian Institution, Washington, DC.

Smodlaka, H., Henry, R. W. \& Reed, R. B. 2009: Macroscopic anatomy of the ringed seal (Pusa (Phoca) hispida) lower respiratory system. — Anatomia Histologia Embryologia 38: 177-183.

Ukkonen, P., Aaris-Sørensen, K., Arppe, L., Daugnora, L., Halkka, A., Lōugas, L., Oinonen, M. J., Pilot, M. \& Storå, J. 2014: An arctic seal in temperate waters: History of the ringed seal (Pusa hispida) in the Baltic Sea and its adaptation to the changing environment. - The Holocene 24: 1694-1706.

Usenius, T., Mustonen, A.-M., Usenius, J.-P., Hyvärinen, H., Sipilä, T., Koskela, J. T. \& Nieminen, P. 2007: Magnetic resonance imaging and its applications in morphological studies of pinnipeds. - Annales Zoologici Fennici 44: 355-367.

Valtonen, M., Palo, J. U., Ruokonen, M., Kunnasranta, M. \& Nyman, T. 2012: Spatial and temporal variation in genetic diversity of an endangered freshwater seal. Conservation Genetics 13: 1231-1245.

Weijs, W. A., Brugman, P. \& Klok, E. M. 1987: The growth of the skull and jaw muscles and its functional consequences in the New Zealand rabbit (Oryctolagus cuniculus). — Journal of Morphology 194: 143-161. 